\title{
Producción y caracterización de un anticuerpo policlonal dirigido contra la fosfoproteína del virus de la rabia
}

\author{
Nadia Yadira Castañeda ${ }^{1,2}$, Jacqueline Chaparro-Olaya ${ }^{3,4}$, Jaime E. Castellanos ${ }^{1,2}$ \\ ${ }^{1}$ Instituto de Virología, Universidad El Bosque, Bogotá, D. C., Colombia \\ ${ }^{2}$ Laboratorio de Neurociencias, Instituto Nacional de Salud, Bogotá, D. C., Colombia \\ ${ }^{3}$ Laboratorio de Parasitología Molecular, Universidad El Bosque, Bogotá, D. C., Colombia \\ ${ }^{4}$ Laboratorio de Bioquímica, Instituto Nacional de Salud, Bogotá, D. C., Colombia \\ El trabajo fue realizado en los Laboratorios de Neurociencias y Bioquímica del Instituto Nacional de Salud y \\ el Instituto de Virología de la Universidad El Bosque
}

Introducción. La producción de una proteína viral recombinante facilita la aplicación de diversas metodologías bioquímicas en investigación básica de los virus con relevancia clínica. Además, la obtención de un anticuerpo policlonal dirigido contra la proteína $\mathrm{P}$ permite el estudio de su función y está soportado en la inexistencia de un anticuerpo comercial dirigido contra esa proteína.

Objetivo. Producir y caracterizar un anticuerpo policlonal dirigido contra la proteína $\mathrm{P}$ recombinante del virus de la rabia expresada en Escherichia coli.

Materiales y métodos. El gen $P$ que codifica para la proteína $P$ del virus de la rabia, fue amplificado por reacción en cadena de la polimerasa de transcriptasa reversa y clonado en el vector de expresión PinPoint ${ }^{\mathrm{TM}}$ Xa-1 T (PROMEGA). La proteína recombinante P fue expresada en $E$. coli purificada por cromatografía de afinidad y usada para la producción del anticuerpo policlonal anti-P. El anticuerpo obtenido fue purificado y caracterizado por inmunocitoquímica con un sistema enzimático, inmunofluorescencia, Cell-ELISA fluorométrica y Western blotting. Resultados. La proteína recombinante se expresó eficientemente como una proteína de fusión biotinilada de aproximadamente $50 \mathrm{kd}$, que corresponde a la forma completa de la proteína $\mathrm{P}$ del virus de la rabia. El anticuerpo policlonal anti-P detectó con alta especificidad la proteína $P$ en cultivos de neuronas sensoriales infectados con el virus de la rabia.

Conclusión. La proteína $\mathrm{P}$ recombinante expresada en $E$. coli se constituyó en un antígeno específico para producir un anticuerpo policlonal que reconoce la proteína $\mathrm{P}$ nativa en células infectadas con el virus de la rabia.

Palabras clave: virus de la rabia, inmunoquímica, fosfoproteínas, proteínas recombinantes, Escherichia coli.

Production and characterization of a polyclonal antibody against rabies virus phosphoprotein

Introduction. The expression of recombinant viral proteins has been a useful tool to study molecular biology and pathogenesis of virus infections. Because commercial specific antibodies to rabies virus phosphoprotein $(P)$ are currently unavailable, these antibodies must be generated de novo in order to study the role of $\mathrm{P}$ protein during the infectious process.

Objective. A polyclonal antibody was produced and characterized for use against the phosphoprotein $(\mathrm{P})$ of rabies virus. The antibody was raised in rabbits with a recombinant viral phosphoprotein $(\mathrm{P})$ produced in Escherichia coli.

Materials and methods. Gene P coding for the viral phosphoprotein $(P)$ was amplified by RT$\mathrm{PCR}$ and cloned into the expression vector PinPointTM Xa-1 T. The recombinant protein $\mathrm{P}$ was expressed in Escherichia coli, purified by affinity chromatography and used to produce a polyclonal antibody anti-P. The antibody anti-P was purified and characterized by immunocytochemistry, immunofluorescence, fluorometric CELL-ELISA and Western blotting. 
Results. The recombinant viral phosphoprotein was successfully expressed as a $50 \mathrm{kd}$ biotinylated fusion protein which corresponds to the whole protein $\mathrm{P}$ of rabies virus. The polyclonal antibody raised against this recombinant protein $\mathrm{P}$ was able to detect with high specificity, protein $P$ in cultures of sensorial neurons infected with rabies virus.

Conclusions. The $\mathrm{P}$ protein obtained from heterologous expression in Escherichia coli became a specific antigen that was used to produce a polyclonal antibody capable of detecting native $P$ protein in rabies virus infected cells.

Key words: rabies virus, immunochemistry, phosphoproteins, recombinant proteins, Escherichia coli.

Un reporte de la Organización Mundial de la Salud estimó que cada año ocurren entre 40.000 y 70.000 muertes por encefalomielitis rábica (1), principalmente, debido a la ausencia de un óptimo protocolo para el tratamiento posterior a la exposición, para vacunación humana y seroterapia (2).

Además de que las infecciones por virus de la rabia continúan siendo un problema de salud pública en países en vías de desarrollo, el virus per se constituye en un modelo experimental completo para el estudio de las interacciones entre los virus neurotrópicos y la maquinaria celular neuronal.

La comprensión de los mecanismos de entrada y propagación usados por el virus de la rabia aporta al conocimiento de la patogenia de otros virus que ocasionan daño al sistema nervioso. Asimismo, el estudio de la biología molecular del virus fortalece el entendimiento de la interacción virushuésped que, finalmente, aporta al mejoramiento de la vacuna existente y al diseño de nuevas terapias antivirales.

Los mecanismos de transcripción y replicación usados por el virus de la rabia siguen siendo objeto central de investigación, ya que la participación de las proteínas virales en dichos eventos no ha sido dilucidada en forma completa. Actualmente, se sabe que la fosfoproteína del virus de la rabia (proteína P) es un componente del complejo ribonucleoproteína (RNP), donde interactúa con la nucleoproteína (proteína N) y con la ARN polimerasa virales. La proteína $P$ es susceptible de ser fosforilada y los estudios recientes han

\footnotetext{
Correspondencia:

Jaime E. Castellanos, transversal 9A Bis \#132-55, Edificio de Rectoría, laboratorio 205, Universidad El Bosque, Bogotá D. C., Colombia.

castellanosjaime@unbosque.edu.co

Recibido: 07/11/06; aceptado: 28/03/07
}

identificado dos tipos de cinasas que fosforilan la proteína de manera diferencial, lo cual sugiere un mecanismo regulador del ciclo viral (3).

La proteína $P$ también interactúa con una proteína celular implicada en el transporte retrógrado (4), lo cual sugiere que la interferencia de las funciones de la $\mathrm{P}$ podría tener efectos deletéreos sobre el ciclo viral $(2,4)$.

Considerando la potencial versatilidad funcional de la proteína $\mathrm{P}$, esta fosfoproteína se vislumbra como un excelente blanco para el diseño de inhibidores de la transcripción y replicación viral $y$, además, teniendo en cuenta su multifuncionalidad, se hace valiosa la propuesta de indagar sobre su función en la replicación viral.

Con este propósito, en este trabajo se usó como estrategia experimental la expresión de la proteína $P$ recombinante en un sistema procariote, la cual se constituyó en una herramienta útil para evaluar la función de $\mathrm{P}$ en el ciclo viral. Por tanto, se llevó a cabo la producción de un anticuerpo policlonal a partir de la proteína $\mathrm{P}$ recombinante, el cual permitirá en estudios posteriores evaluar aspectos como la síntesis, la distribución subcelular y el transporte de la proteína $P$ en cultivos neuronales infectados con el virus de la rabia, con la finalidad de responder a algunos interrogantes acerca de la participación de la $\mathrm{P}$ en el ciclo viral.

\section{Materiales y métodos \\ Clonación del gen P del virus de la rabia}

El gen $P$ del virus de la rabia fue clonado como se describió previamente (Castañeda N, Chaparro $\mathrm{J}$, Castellanos JE. Tecnología de la clonación y expresión génica en un sistema bacteriano y su aplicación en virología. Revista Escuela Colombiana de Medicina 2007. En prensa). 
En forma breve, mediante el método del trizol (INVITROGEN), se extrajo el ARN total a partir de cerebro de ratón infectado con virus de la rabia (cepa CVS-11). A continuación, se hizo transcripción reversa usando un iniciador oligod $(\mathrm{T})$. Con base en la secuencia del gen de la fosfoproteína (gen $P$ ) de la cepa CVS-11 del virus de la rabia, se diseñaron los iniciadores específicos sentido PF-KpnI (5' TCG-GTA-CCATGA-GCA-AGA-TCT-TTG-TTA-ATC-3') y antisentido, PR-Smal (5' ATC-CCG-GGT-CGGGTT-AGC-AGG-ATG-TAT-AGC 3').

Las condiciones de amplificación de la reacción en cadena de la polimerasa (PCR) fueron: un ciclo de $94^{\circ} \mathrm{C} / 2$ minutos; 30 ciclos de $94^{\circ} \mathrm{C} / 45 \mathrm{~s}, 65^{\circ} \mathrm{C} /$ $90 \mathrm{~s}, 72^{\circ} \mathrm{C} / 60 \mathrm{~s}$ y un ciclo de $72^{\circ} \mathrm{C} / 3$ minutos. El producto de PCR fue purificado con el kit QIAquick Gel Extraction (QIAGEN) y clonado en el vector pGEMT-Easy (PROMEGA). Se hizo después transformación de bacterias E. coli (JM109). La presencia del inserto correcto se confirmó por PCR, restricción enzimática y determinación de la secuencia.

\section{Expresión del gen $P$ del virus de rabia y purificación de la proteína $P$}

El inserto fue subclonado en el vector de expresión PinPoint ${ }^{\mathrm{TM}} \mathrm{Xa}-1 \mathrm{~T}$ (PROMEGA) y la expresión de la proteína $P$ fue inducida por adición de isopropil$\beta$-D-tiogalactopiranósido (IPTG) a cultivos de $E$. coli (JM109). La expresión de la proteína $P$ se confirmó por inmunoblot de extractos bacterianos crudos, debido a que el sistema usado produce proteínas de fusión biotiniladas. La proteína $\mathrm{P}$ se detectó por reacciones enzimáticas con estreptavidina acoplada a fosfatasa.

La proteína $P$ recombinante fue purificada por cromatografía de afinidad usando la resina Softlink (Promega), la cual está acoplada a avidina y permite la purificación de proteínas biotiniladas. El lisado celular bacteriano que contenía la proteína de fusión biotinilada se sometió a un proceso de captura en batch, en el cual la resina y el lisado celular permanecieron en contacto durante cuatro horas. Después de la captura se hizo la elución de la proteína biotinilada durante 16 horas usando un tampón de elución (Tris- $\mathrm{HCl}$ pH
$7,5, \mathrm{NaCl} 150 \mathrm{mM}$ ) que contiene un exceso de biotina y que permitió la liberación de la proteína de fusión. Una vez purificada la proteína $P$ recombinante, se cuantificó usando el método de ácido bicinconínico.

\section{Preparación del antígeno, inmunización y purificación del anticuerpo}

Para la producción del anticuerpo policlonal, se usaron dos conejos Nueva Zelanda, machos, de ocho semanas de edad. El procedimiento de inmunización de los conejos se realizó con la aprobación del Comité de Ética de la Facultad de Medicina de la Universidad Nacional. Antes de iniciar el esquema de inmunización en los conejos, se obtuvo una muestra de $5 \mathrm{ml}$ de sangre de una de las venas marginales de la oreja de cada conejo para obtener el suero preinmune que posteriormente sería usado como control negativo.

Los conejos se inocularon por vía subcutánea con una mezcla de adyuvante completo de Freund y $500 \mu \mathrm{g}$ de proteína $\mathrm{P}$ recombinante por cada conejo. Se reforzó la inoculación en los días 14, 30 y 45 después de la primera inoculación primaria, con una nueva dosis subcutánea de antígeno (250 $\mathrm{\mu g}$ por conejo) preparado en adyuvante incompleto de Freund.

En el día 45 se recolectó $1 \mathrm{ml}$ de sangre de cada conejo inoculado y se realizaron experimentos de inmunocitoquímica para evaluar el título de anticuerpos séricos específicos contra la proteína $\mathrm{P}$ del virus de la rabia. En el día 60 se practicó la recolección del volumen sanguíneo total (exsanguination) bajo anestesia profunda de los animales. La fracción de inmunoglobulinas del suero policlonal se purificó por precipitación con sulfato de amonio. Finalmente, el anticuerpo policlonal anti-P purificado se preservó en PBS y $50 \%$ de glicerol estéril y se almacenó a $-20^{\circ} \mathrm{C}$.

\section{Análisis por inmunocitoquímica y por inmunofluorescencia}

Para la caracterización del anticuerpo policlonal anti-P, inicialmente se realizaron ensayos de inmunoperoxidasa indirecta e inmunofluorescencia sobre cultivos de neuronas de ganglio de raíz dorsal de ratón adulto. Aproximadamente, 2.000 
neuronas se sembraron en cajas de 24 pozos sobre laminillas tratadas con poli-L-lisina, infectadas al día 3 de cultivo con virus de la rabia cepa CVS11 en una dilución 1/100 (MOI: 0,03) y fijadas durante 30 minutos con PFA $4 \%$ a las 26 horas después de la inoculación (5).

Las células infectadas se detectaron con el anticuerpo policlonal producido contra la proteína $P$ recombinante del virus de la rabia, el cual se preparó en solución tampón de bloqueo (PBS 1X, ASB $1 \%$, suero de bovino recién nacido $10 \%$, Tween 20 0,05\%) en diluciones de 1/300, 1/600 y $1 / 1.200$ y se incubó durante 30 minutos a $37^{\circ} \mathrm{C}$. El anticuerpo policlonal anti-nucleocápside (BIORAD Catálogo 357-2114) se usó como control positivo y se incubó en las mismas condiciones descritas para el anticuerpo anti-P, pero en una dilución de 1/100.

Luego, se adicionó un anticuerpo biotinildado antiIgG de conejo (Vector Labs) en una dilución 1/200 durante 30 minutos a temperatura ambiente, seguido por incubación con estreptavidina acoplada a peroxidasa ( $2 \mu \mathrm{g} / \mathrm{ml}$ Vector Labs) por 30 minutos a temperatura ambiente. El revelado se llevó a cabo con una mezcla $1: 1$ de $\mathrm{H}_{2} \mathrm{O}_{2}$ al $0,02 \%$ en agua y diaminobenzimida al $1 \%$ en Tris $\mathrm{HCl} \mathrm{pH} \mathrm{7,2.}$

El procesamiento que se realizó para inmunofluorescencia fue similar al descrito para la técnica de inmunoperoxidasa, usando estreptavidina acoplada a isotiocionato de fluoresceína (FITC) a una concentración final de $2 \mu \mathrm{g} / \mathrm{ml}$ (Sigma). Las láminas se observaron en un microscopio de epifluorescencia Olimpus BX 50 para analizar y describir el patrón de marcación específico obtenido con el anticuerpo anti-P.

\section{Ensayo de cell-ELISA fluorométrica}

Se empleó una cell-ELISA fluorométrica estandarizada en nuestro laboratorio (6). Las células se sembraron en cajas de 96 pozos (Corning 25870), se fijaron con paraformaldehído al $4 \%$ por 30 minutos después de 16,26 y 36 horas de la infección. Se utilizó el anticuerpo policlonal producido contra la proteína $P$ recombinante del virus de la rabia, en diferentes concentraciones, el cual se preparó en tampón de bloqueo (TBS 1X, ASB 1\%, suero de bovino recién nacido $10 \%$, Tween20 0,05\%) durante 30 minutos a $37^{\circ} \mathrm{C}$.

Después de lavar con TBS, se incubó por 30 minutos a temperatura ambiente con el anticuerpo secundario biotinilado, anti-lgG de conejo (Vector Labs. BA9200). Nuevamente se lavó con TBS y se agregó la enzima estreptavidina conjugada a fosfatasa alcalina (1/250, SA5100 Vector Labs) por 30 minutos a temperatura ambiente.

Por último, se adicionó un substrato fluorogénico, el 4-metil-umbeliferilfosfato (MUP 3,6 mM, Molecular Probes, M-6491) preparado en tampón de revelado $\left(\mathrm{NaCl} 0,1 \mathrm{M}\right.$, Tris $100 \mathrm{mM}$ y $\mathrm{MgCl}_{2} 50$ $\mathrm{mM}, \mathrm{pH} 9,5)$ y se realizó la medición de fluorescencia a diferentes tiempos en un fluorómetro PR-521 (TecnoSuma, La Habana, Cuba) con filtros de excitación de $360 \mathrm{~nm}$ y emisión de $450 \mathrm{~nm}$.

Para normalizar los datos se utilizó el método del ácido bicinconínico para cuantificar la cantidad de proteína total en cada uno de los pozos $(7,8)$. La concentración de proteína se determinó interpolando los datos de absorbancia en una curva de calibración con concentraciones conocidas de albúmina sérica bovina.

\section{Análisis por Western blotting}

El anticuerpo policlonal anti-P se usó para detectar la proteína viral en lisados celulares totales infectados obtenidos a partir de cultivos de neuronas de ganglio de raíz dorsal e inmovilizados en membranas de polifluoruro de vinilideno (PVDF). Los cultivos neuronales se mantuvieron en cajas de $35 \mathrm{~mm}$ y se infectaron con virus de la rabia cepa CVS-11 a un MOI 0,03.

A las 26 horas después de la infección, las células se lisaron con solución tampón RIPA (PBS 1X, IGEPAL $1 \%$, deoxicolato de sodio $0,1 \%$, SDS $0,1 \%$ ). Luego de centrifugar por 20 minutos a $4^{\circ} \mathrm{C}$, se obtuvo y cuantificó el lisado celular total de cultivos neuronales sin infectar y los cultivos neuronales infectados con el virus de la rabia.

En un gel de poliacrilamida al $11 \%$ se separaron electroforéticamente $200 \mathrm{mg}$ de proteína total obtenida de los lisados celulares totales infectados 
y los no infectados en condiciones denaturantes y reductoras. Las proteínas separadas se transfirieron a una membrana de PVDF durante 16 horas a $30 \mathrm{~V}(300 \mathrm{~mA})$. La membrana se incubó con el anticuerpo policlonal anti-P a una concentración de $30 \mu \mathrm{g} / \mathrm{ml}$ preparado en solución de bloqueo durante 30 minutos a $37^{\circ} \mathrm{C}$. Luego se adicionó un anticuerpo anti-IgG de conejo biotinilado durante 30 minutos a temperatura ambiente y se incubó la membrana con estreptavidina acoplada a peroxidasa por 30 minutos a temperatura ambiente. El revelado de la membrana fue llevado a cabo con $\mathrm{DAB} / \mathrm{H}_{2} \mathrm{O}_{2}$.

\section{Resultados}

Clonación y expresión del gen de la fosfoproteína del virus de la rabia

Los resultados de la clonación del gen $\mathrm{P}$ fueron descritos previamente (Castañeda N, Chaparro J, Castellanos JE. Tecnología de la clonación y expresión génica en un sistema bacteriano y su aplicación en virología. Revista Escuela Colombiana de Medicina 2007. En prensa). Para dos clones, la secuencia obtenida (GenBank Accesion number DQ011221) se tradujo y se comparó con la proteína $\mathrm{P}$ del virus de la rabia cepa CVS-11 reportada (NCBI, X55727); ambos clones mostraron un $98 \%$ de homología (cinco aminoácidos cambiados, ninguno de ellos corresponde a los sitios conocidos de fosforilación de la proteína P).

Usando un sistema de revelado con fosfatasa alcalina se detectaron las proteínas de fusión biotiniladas producidas por la transformación de E. colicon el vector PinPoint ${ }^{\mathrm{TM}} \mathrm{Xa}-1 \mathrm{~T}$ (figura $\left.1 \mathrm{~A}\right)$. La única proteína biotinilada expresada endógenamente por $E$. colise detectó como una banda de 22,5 kd; el péptido señal incorporado en el vector de expresión también se detectó con un peso molecular de $13 \mathrm{kd}$ en el extracto de bacterias transformadas con el vector sin inserto.

Asimismo y de manera muy eficiente, se expresó la proteína $\mathrm{P}$ recombinante en $E$. coli. El sistema de expresión usado produjo una proteína de fusión biotinilada de $50 \mathrm{kd}$, aproximadamente; la proteína $P$ silvestre tiene un peso molecular de $37 \mathrm{kd} \mathrm{y} \mathrm{el}$ péptido señal biotinilado, $13 \mathrm{kd}$, que corresponde

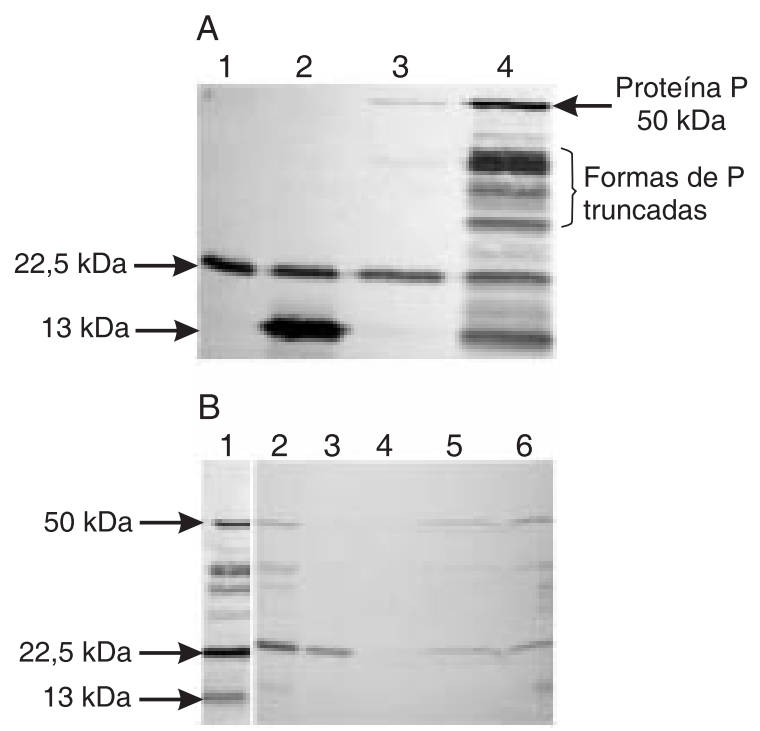

Figura 1. Expresión y purificación de la proteína $P$ recombinante. A. Blot de proteínas de fusión biotiniladas expresadas en el vector PinPoint ${ }^{\mathrm{TM}} \mathrm{Xa}-1 \mathrm{~T}$. Carril 1: bacterias JM109 sin vector; carril 2: bacterias JM109 con vector; carril 3: bacterias JM109 que contienen el vector con inserto sin inducción de la expresión; carril 4: bacterias JM109 que contienen el vector con inserto a las 4 horas de inducción de la expresión. B. Purificación: blot revelado con un sistema de fosfatasa alcalina. Carril 1: extracto sin purificar; carril 2: fracción no unida a la resina; carriles 3 y 4 : lavados de la resina; carriles 5 y 6 : eluídos 1 y 2 con la proteína $P$ purificada.

a la forma completa de la proteína $\mathrm{P}$ del virus de rabia (figura $1 \mathrm{~A}$ ).

Además, las formas truncadas de la proteína $P$ (9) se expresan y detectan como proteínas de fusión biotiniladas de tamaño más pequeño.

\section{Purificación y cuantificación de la proteína P recombinante}

A diferencia de la gran eficiencia en la expresión de la proteína $P$ recombinante, la purificación por cromatografía de afinidad mostró poca eficiencia y, aunque las proteínas de fusión biotiniladas se purificaron, hubo necesidad de repetir en varias oportunidades la expresión en E. colide la proteína hasta obtener $2 \mathrm{mg}$ de proteína recombinante contenida en $4 \mathrm{ml}$ de eluído con una concentración de $500 \mathrm{mg} / \mathrm{ml}$, cantidad suficiente para inmunizar los conejos.

La eficiencia en la purificación de las diferentes formas de $\mathrm{P}$ fue diferencial; la forma completa de 


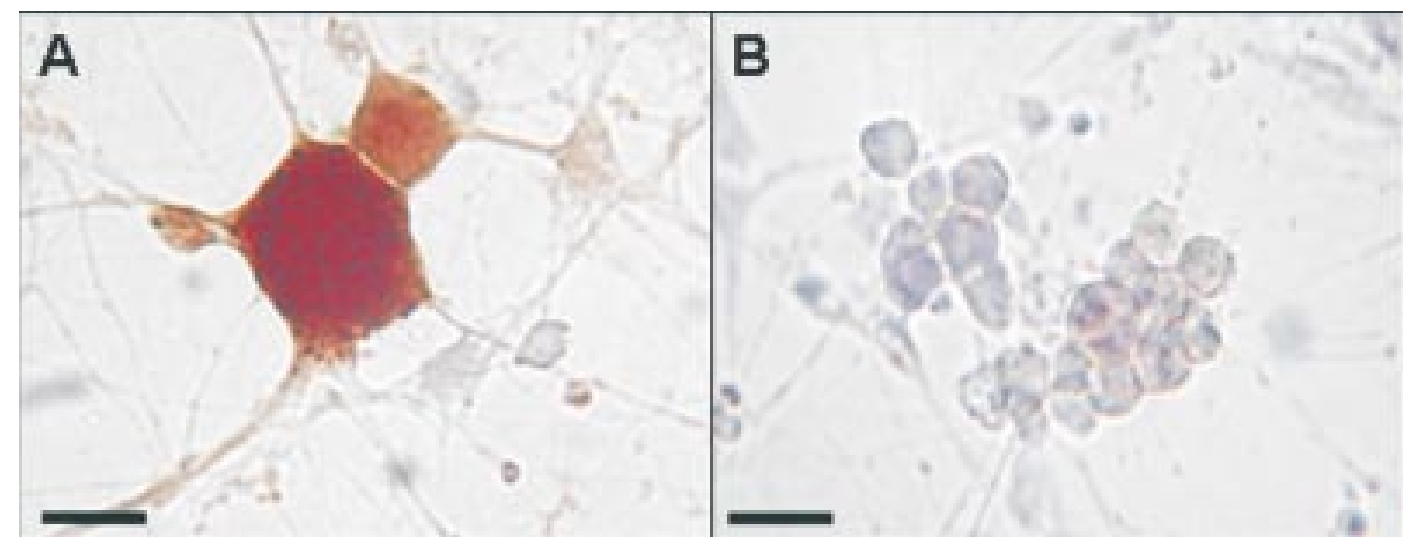

Figura 2. Ensayo de inmunoperoxidasa indirecta para la detección de la proteína $P$ con el anticuerpo policlonal anti-P. En cultivos de neuronas de ganglio de la raíz dorsal infectados con virus de rabia, se observan células neuronales inmunoreactivas (A). B, control sin infección. Las barras corresponden a $20 \mu \mathrm{m}$ en A y a $40 \mu \mathrm{m}$ en $\mathrm{B}$.

P se detectó predominantemente después del proceso de elución (figura 1B).

\section{Caracterización del anticuerpo anti-P}

\section{Inmunocitoquímica}

En los ensayos de inmunoperoxidasa se usaron concentraciones entre 10 y $50 \mathrm{~g} / \mathrm{ml}$ del anticuerpo policlonal anti-P. La proteína $\mathrm{P}$ se detectó con una concentración de $15 \mu \mathrm{g} / \mathrm{ml}$ del anticuerpo en cultivos de neuronas infectadas con virus de la rabia cepa CVS-11 (figura 2A). El antígeno se detectó en el citoplasma, donde se observaron pequeñas vesículas inmunorreactivas. En contraste, en las células no infectadas no se observó inmunorreactividad con el anticuerpo (figura 2B), de igual manera que cuando se usó el suero preinmune como control sobre células infectadas.

\section{Inmunofluorescencia}

En los ensayos de inmunofluorescencia la proteína $\mathrm{P}$ del virus de la rabia se detectó en cultivos infectados usando el anticuerpo policlonal anti-P $(36 \mu \mathrm{g} / \mathrm{ml})$ describiendo un patrón de marcación citoplasmática definido, en vesículas de menor tamaño que las descritas para el anticuerpo anti-nucleocápside. Además, se observó un patrón de tinción granular fino más concentrado hacia la superficie celular, el cual se extendía en los procesos neuríticos, donde se observaron "várices" (varicosities) discretas con una inmunotinción intensa (figura 3A).
La marcación fue específica para células infectadas (en células no infectadas no se observó inmunofluorescencia, figura 3B) y predominantemente en neuronas grandes, con tinción ocasional de células no neuronales, lo cual establece diferencias en el patrón de distribución con respecto a la detección en células neuronales y no neuronales del complejo nucleocápside cuando se usa el anticuerpo BIORAD (figura 3C).

El patrón de marcación definido por el anticuerpo policlonal anti-P es claramente distinguible de la tinción descrita por los anticuerpos antinucleocápside y anti-proteína $\mathrm{G}$. Las vesículas citoplasmáticas características de la marcación con el anticuerpo anti-nucleocápside (figura 3C) son de mayor tamaño, explicable por el complejo proteico que el anticuerpo detecta, los procesos 'neuríticos' tienen una marcación continua menos granular y que describe aparentemente un proceso 'neurítico' de mayor grosor comparado con las finas y discretas "várices" (varicosities) donde se detecta la proteína $P$.

Con respecto a la detección de la glicoproteína del virus con el anticuerpo PVE12 (figura 3D), se observó un patrón de marcación difuso y denso en las células infectadas; no se describe una tinción fina ni granular como la obtenida en la detección de la proteína $P$.

Por otra parte, el patrón de tinción en las células no neuronales fue citoplasmático disperso sin la 

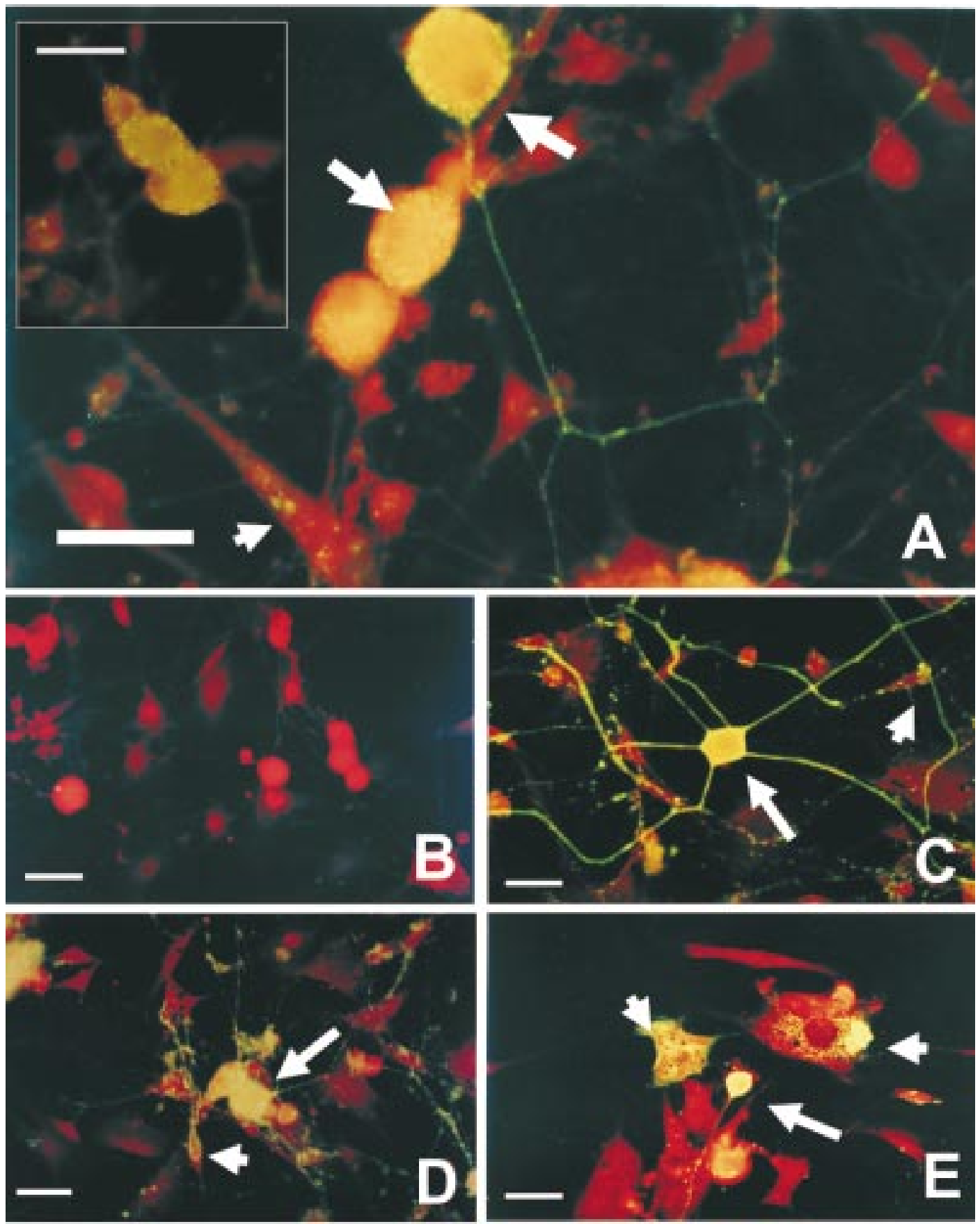

Figura 3. Expresión de la proteína $P$ en cultivos de neuronas de ganglio de la raíz dorsal infectados con virus de la rabia. Inmunofluorescencia que muestra el patrón de marcación descrito con el anticuerpo policlonal anti-P en células neuronales infectadas (A) y ausencia de marcación en células no infectadas (B). Patrón de marcación con anticuerpos BIORAD y PVE12 (C y D) y patrón de marcación descrito con el anticuerpo policlonal anti-P en células no neuronales infectadas (E). Las neuronas infectadas se señalan con flechas y las células no neuronales infectadas con cabeza de flecha. Las barras corresponden a $40 \mu \mathrm{m}(\mathrm{A}, \mathrm{B}, \mathrm{C}, \mathrm{D}$ y $\mathrm{E})$ y a $100 \mu \mathrm{m}$ en el detalle del recuadro $\mathrm{A}$. 
tendencia a la marcación granular fina en la superficie celular (figura 3E). Además, la marcación de células no neuronales fue muy evidente cuando se usaron los dos anticuerpos de control, en contraste con la marcación casi absolutamente neuronal descrito por el anticuerpo policlonal anti-P.

Los resultados muestran, de esta manera, un patrón diferencial de tinción en la detección de la proteína $\mathrm{P}$ comparado con la marcación descrita por la detección del complejo proteico de la nucleocápside y de la glicoproteína del virus de la rabia, lo cual permitiría posteriormente evaluar más finamente la localización particular subcelular de la proteína $P$.

\section{Ensayos de fluorometría}

El anticuerpo anti-P también se usó en ensayos de fluorometría en diferentes concentraciones y una concentración de $15 \mathrm{mg} / \mathrm{ml}$ fue la óptima para la detección del antígeno en tres tiempos diferentes de infección. A esta concentración del anticuerpo, se evaluó de manera confiable el nivel relativo de expresión de la proteína $P$, ya que la fluorescencia inespecífica detectada por el sistema en los controles sin virus es similar al valor de fluorescencia inespecífica detectada en los controles sin virus usando el anticuerpo monoclonal de referencia PVE12 (dirigido contra la glicoproteína del virus). Este anticuerpo fue previamente avalado para la detección de antígeno viral por la técnica fluorométrica (6). Los valores de cuantificación para las proteínas $P$ y $G$ difieren significativamente debido a que la glucoproteína es sintetizada en mayor a cantidad a través del ciclo viral (figura 4).

\section{Western blotting}

Por último, el anticuerpo policlonal anti-P fue caracterizado por Western blotting. La proteína $P$ se detectó en lisados celulares infectados con virus de la rabia como una única banda de $37 \mathrm{kd}$ usando el anticuerpo policlonal a una concentración de $30 \mathrm{mg} / \mathrm{ml}$ (figura 5).

Teniendo en cuenta los resultados obtenidos por las técnicas de inmunocitoquímica, fluorometría y Western blot ,se puede afirmar que el anticuerpo policlonal anti-P reconoce específicamente a la

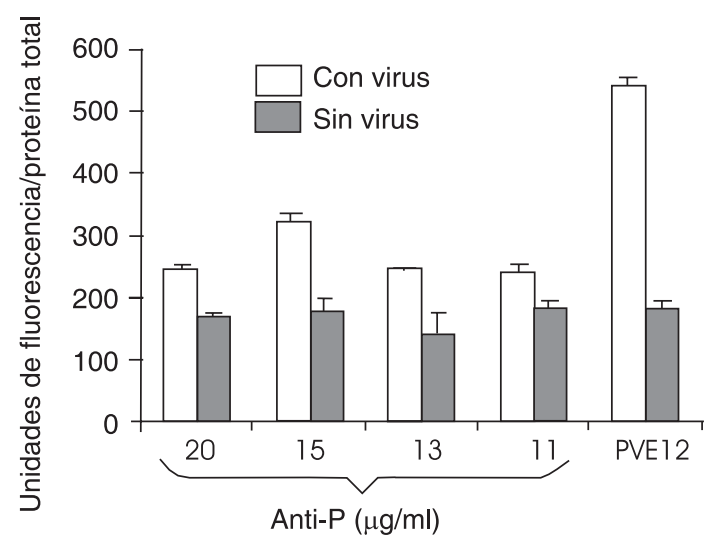

Figura 4. Caracterización del anticuerpo policlonal anti-P por la técnica fluorométrica. El anticuerpo anti-P se usó en concentraciones entre 20 y $11 \mu \mathrm{g} / \mathrm{ml}$ en neuronas de ganglio de la raíz dorsal infectadas con virus de la rabia. Los valores corresponden a la media de un experimento con cuatro réplicas para cada condición $\pm \operatorname{EEM}(n=4)$. Nótese que la señal de fluorescencia detectada en los controles sin virus es igual usando el anticuerpo policlonal anti-P y el anticuerpo monoclonal PVE12.

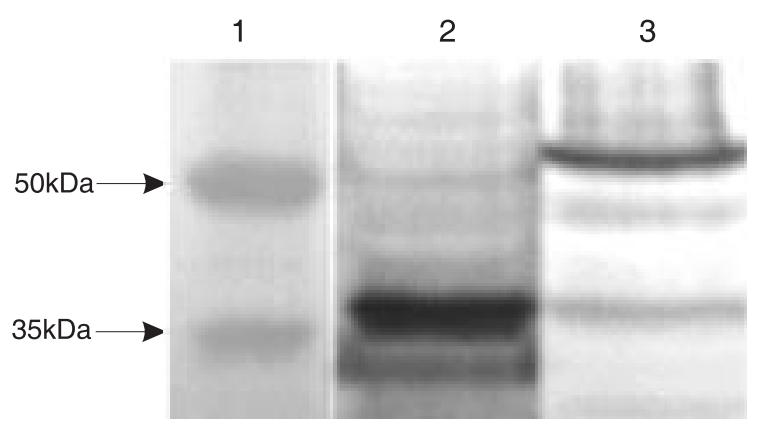

Figura 5. Detección de la proteína $\mathrm{P}$ por Western blotting. Lisados celulares infectados con el virus de la rabia cepa CVS-11 fueron sometidos a SDS-PAGE y Western blot con el anticuerpo policlonal anti-P (carril 2). El anticuerpo antinucleocápside se usó como control positivo sobre el mismo lisado celular infectado (carril 3). Nótese la fuerte banda de $37 \mathrm{kd}$ que corresponde a la proteína P. El carril 1 corresponde al marcador de peso molecular.

proteína $\mathrm{P}$ del virus de la rabia en cultivos de neuronas de ganglio de la raíz dorsal infectados y que es una valiosa herramienta para el estudio de su función en el ciclo viral.

\section{Discusión}

Recientemente, el gen para la nucleoproteína del virus de la rabia fue clonado, secuenciado y expresado en $E$. coli para su uso como reactivo diagnóstico (10). 
A nuestro grupo le interesa particularmente investigar el papel de la proteína $\mathrm{P}$ del virus de la rabia en los eventos de transcripción y replicación viral. Por tanto, la proteína recombinante $\mathrm{P}$ obtenida en este trabajo se usará como herramienta molecular para realizar ensayos de fosforilación in vitro que ayuden a esclarecer la participación de la $P$ en diferentes eventos del ciclo viral.

También se usará en ensayos de co-inmunoprecipitación con la nuceloproteína para evaluar la formación de complejos N-P en cultivos de neuronas infectadas y tratados con neurotrofinas, lo cual podría aportar al entendimiento del efecto antiviral ejercido por estos factores neurotróficos.

En trabajos previos, se han usado las proteínas virales recombinantes, por ejemplo, para la caracterización de moléculas que podrían estar involucradas en los procesos de adhesión y entrada del virus. La aproximación experimental en dichos estudios consiste en usar la proteína recombinante como ligando en un ensayo de cromatografía de afinidad (11).

De la misma manera, el receptor de ratón para neurotrofinas $p 75$ se postuló como una molécula receptora para el virus de la rabia usando una estrategia de clonación y expresión de la glucoproteína del virus (12); se evidenciaron las interacciones directas entre la glicoproteína del virus de la rabia y p75 y se identificaron los dominios de unión en ambas moléculas (13).

El plásmido recombinante construido en este trabajo que codifica para el gen completo $\mathrm{P}$ permitió la expresión eficiente de la forma completa (P1) y las formas truncadas de P (P2$P 5)$. Se ha demostrado que las formas $P 1$ y $P 2$ se localizan en el citoplasma pero las formas P3P5 se encuentran, principalmente, en el núcleo. Estos productos nucleares del gen $\mathrm{P}$ interactúan con la proteína de leucemia promielocítica (PML) inducida por interferón en complejos multi-proteína llamados cuerpos nucleares, que podrían estar involucrados en un mecanismo de defensa celular contra la infección viral (14).

Con respecto a los cambios encontrados en la secuencia traducida para la proteína $P$ recombinante, es posible que se deban a una variabilidad inherente a los virus $A R N$, como el virus de la rabia, y sean promovidos por el sistema biológico usado para obtener virus purificado en condiciones experimentales (el virus purificado ha sido sometido a varios pasajes en cerebro de ratón).

El acceso comercial a los anticuerpos dirigidos contra las proteínas del virus de la rabia ha significado un inconveniente, especialmente para nuestro grupo, en el proceso de investigación sobre la patogenia y replicación del virus. Aunque un panel de anticuerpos monoclonales dirigidos contra la proteína $P$ ha sido generado y caracterizado en trabajos previos $(15,16)$, no existe aun un anticuerpo disponible comercialmente.

El trabajo realizado aporta un producto tecnológico que apoya el estudio de la función de la proteína P; el anticuerpo policlonal producido representa una valiosa aproximación experimental para la investigación de los mecanismos de participación de la proteína $P$ en la regulación de eventos como transcripción y replicación viral. La detección del antígeno $P$ fue muy específica y de gran versatilidad técnica, de manera que en ensayos de fluorometría, inmunofluorescencia e inmunoblot fue adecuada la utilización del anticuerpo policlonal anti-P producido en conejo.

Motoi et al. (2005) detectaron la proteína viral P en el citoplasma de neuronas de ganglio trigémino usando el anticuerpo policlonal obtenido en gallina $y$, aunque no describieron en detalle el patrón de inmunotinción, se puede observar que, al igual que en nuestro trabajo, detectaron la proteína $P$ en vesículas pequeñas localizadas en la periferia del citoplasma.

El anticuerpo policlonal producido por nuestro grupo fue caracterizado por inmunocitoquímica, inmunofluorescencia, Western blot y cell-ELISA en células infectadas con virus de la rabia y no infectadas, a diferencia del trabajo previo realizado, en el cual la caracterización del anticuerpo policlonal se hizo usando inmunohistoquímica y Western blot; sin embargo, en este último el anticuerpo no fue ensayado sobre células infectadas y no infectadas sino sobre proteína purificada a partir de un inóculo viral de la cepa CVS-11 (17). 
Por otro lado, el patrón de marcación descrito por el anticuerpo anti-P en los ensayos de inmunofluorescencia, evidenció una distribución subcelular de la proteína $\mathrm{P}$ muy particular que podría significar un transporte activo de esta proteína viral desde el citoplasma hasta procesos 'neuríticos' y que podría estar relacionado con la participación de $\mathrm{P}$ en los eventos de propagación viral hacia otras células.

Asimismo, se observó que la proteína $P$ se detectó predominantemente en células neuronales, especialmente en neuronas grandes, en las cuales se ha demostrado mayor susceptibilidad a la infección por virus de la rabia (Martínez-Gutiérrez $\mathrm{M}$, Castellanos JE. Morphological and biochemical characterization of sensory neurons infected in vitro with rabies virus. Acta Neuropathol (Berl) 2007. En prensa). Por consiguiente, se podría pensar que las neuronas tienen, además de mayor susceptibilidad, una maquinaria celular más eficiente para la replicación de este virus, lo cual soportaría aún más la participación de la fosfoproteína en el fuerte neurotropismo evidenciado para el virus de la rabia.

Es posible que en tiempos tempranos de replicación viral, dos factores puedan afectar la detección del antígeno; uno es la disminución de ARN viral, posiblemente, por acción de la ARNsa L y otro, la baja producción de la proteína que escaparía al sistema de detección fluorométrico. De ahí que en tiempos tardíos de la replicación, la expresión diferencial de la proteína podría evaluarse con mayor sensibilidad.

Finalmente, teniendo en cuenta la expresión silvestre de formas truncadas de la proteína $P$ y su localización nuclear y citoplasmática, es relevante confirmar que el anticuerpo policlonal anti-P detecta esas formas truncadas por cuanto se les ha propuesto una función inhibiendo la respuesta antiviral y de esta manera evaluar la implicación de dichas formas en el ciclo viral.

\section{Agradecimientos}

A Felio Bello, profesor de la Universidad de La Salle y a Myriam Velandia, investigadora del Instituto de Virología de la Universidad EI Bosque, por su colaboración en la obtención de las imágenes de microscopía de fluorescencia.

\section{Conflicto de intereses}

Los autores declaran que no tienen intereses particulares que pudieran influenciar los resultados presentados.

\section{Financiación}

El trabajo fue financiado por Colciencias (Proyecto 2104-04-11724) y el Instituto Nacional de Salud (Proyecto 023/2002).

\section{Referencias}

1. World Health Organization. Rabies. Fact Sheet No. 99. Switzerland: WHO Press; 2001.

2. Real E, Rain JC, Battaglia V, Jallet C, Perrin P, Tordo $\mathbf{N}$, et al. Antiviral drug discovery strategy using combinatorial libraries of structurally constrained peptides. J Virol. 2004;78:7410-7.

3. Gupta AK, Blondel D, Choudhary S, Banerjee AK. The phosphoprotein of rabies virus is phosphorylated by a unique cellular protein kinase and specific isomers of protein kinase C. J Virol. 2000;74:91-8.

4. Jacob Y, Badrane H, Ceccaldi PE, Tordo N. Cytoplasmic dynein LC8 interacts with lyssavirus phosphoprotein. J Virol. 2000;74:10217-22.

5. Castellanos JE, Martínez-Gutiérrez $\mathbf{M}$, Hurtado $\mathbf{H}$, Kassis R, Bourhy $\mathrm{H}$, Acosta $\mathrm{O}$, et al. Studying neurotrophin antiviral effect on rabies-infected dorsal root ganglio cultures. J Neurovirol. 2005;11:403-10.

6. Rincón V, Corredor A, Martínez-Gutiérrez M, Castellanos JE. Fluorometric cell-Elisa for quantifying rabies infection and heparin inhibition. J Virol Methods. 2005;127:33-9.

7. Smith PK, Krohn RI, Hermanson G, Mallia A, Gartner FH, Provenzano M, et al. Measurement of protein using bicinchoninic acid. Anal Biochem. 1985;150:76-85.

8. Wiechelman KJ, Braun RD, Fitzpatrick JD. Investigation of the bicinchoninic acid protein assay identification of the groups responsible for color formation. Anal Biochem. 1988;175:231-7.

9. Chenik M, Chebli K, Blondel D. Translation initiation at alternative in-frame AUG codons in the rabies virus phosphoprotein mRNA is mediated by a ribosomal leaky scanning mechanism. J Virol. 1995;69:707-12.

10. He Y, Gao D, Zhang M. Expression of the nucleoprotein gene of rabies virus for use as a diagnostic reagent. J Virol Methods. 2006;138:147-51.

11. Reyes del Valle J, Del Angel RM. Isolation of putative dengue virus receptor molecules by affinity chromatography using a recombinant $\mathrm{E}$ protein ligand. J Virol Methods. 2004;116:95-102. 
12. Tuffereau C, Bénéjean J, Blondel D, Kieffer B, Flamand A. Low-affinity nerve growth factor receptor (p75 ${ }^{\mathrm{NTR}}$ ) can serve as a receptor for rabies virus. EMBO J. 1998;17:7250-9.

13. Langevin C, Jaaro H, Bressanelli S, Fainzilber M, Tuffereau C. Rabies virus glycoprotein (RVG) is a trimeric ligand for the $\mathrm{N}$-terminal cysteine-rich domain of the mammalian p75 neurotrophin receptor. J Biol Chem. 2002;277:37655-62.

14. Blondel D, Regad T, Poisson N, Pavie B, Harper F, Pandolfi PP et al. Rabies virus $P$ and small $P$ products interact directly with PML and reorganize PML nuclear bodies. Oncogene. 2002;21:7957-70.
15. Nadin-Davis SA, Sheen M, Andel-Malik M, Elmgren L, Armstrong J, Wandeler Al. A panel of monoclonal antibodies targeting the rabies virus phosphoprotein identifies a highly variable epitope of value for sensitive strain discrimination. J Clin Microbiol. 2000;38:1397403.

16. Raux H, Iseni F, Lafay F, Blondel D. Mapping of monoclonal antibody epitopes of the rabies virus $\mathrm{P}$ protein. J Gen Virol. 1997;78:119-24.

17. Motoi Y, Inoue S, Hatta H, Sato K, Morimoto K, Yamada A. Detection of rabies-specific antigens by egg yolk antibody ( $\lg Y)$ to the recombinant rabies virus proteins produced in Escherichia coli. Jpn J Infect Dis. 2005;58:115-8. 